\title{
Möteskultur i ungdomsvården
}

\section{MALIN ̊̊KERSTRÖM}

\section{I denna artikel analyseras möteskulturer och mötesstrider mellan olika professionella i ungdomsvården, samt det starka engagemang som ägnas åt dessa möten. Artikeln bygger på en studie av ett samverkansprojekt i ungdoms- vården där ett antal samordnare anställdes. Det visade sig att dessa efter hand kom att upprätthålla en adminis- trativ hällning gentemot varandra, vilket satte det direkta arbetet med unga i skuggan av byråkratiskt och kollegial orientering.}

Det moderna samhället har av den inflytelserika sociologen Charles Perrow (1991) benämnts som "a society of organizations". En stor del av dessas aktiviteter sker i form av möten, som skall vara en plattform för planering, beslutsfattande och diskussioner. Denna möteskultur tycks ha ökat dramatiskt under de senaste femtio åren för affärsvärldens chefer och adminstratörer (Romano och Nunamaker 2001); en situation som kanske inte skiljer sig från det sociala arbetets "gräsrotsbyråkrater" i en alltmer formaliserad socialtjänst?

Malin Åkerström, Professor, Sociologiska institutionen, Lunds universitet
Mötestätheten kan också förväntas tillta då den allt vanligare samverkan med andra organisationer skall utformas och verkställas (Bergmark och Lundström, 2005). I den nutida "projektvärlden" tycks denna mötesaktivitet tillföras nya lager och nivåer då projekt ofta drivs genom referensgrupper samt centrala och lokala arbetsgrupper (jfr Sahlin 1996, Sulkunen 2007).

I ett ungdomsvårdsprojekt tydliggjordes hur denna byråkratiska hållning också kom att karakterisera även de mer verksamhetsnära aktiviteterna, som inledningsvis var tänkta att vara mer personnära, vardagliga och konkreta i förhållande till ungdomarna (Basic, Thelander och Åkerström 2009). 
De anställda samordnarna ägnade istället mycket tid åt och uttryckte ett intensivt engagemang i relation till administrativa och byråkratiska arrangemang. I våra intervjuer och fältanteckningar återfinns denna inriktning i distinktioner mellan dokument och ärenden, recensioner av andra yrkesverksamma samt i ett administrativt språkbruk. Ungdomarna hamnade i en "diskursiv skugga"; när vi granskade såväl intervjuer som fältanteckningar från observationer vi utfört nämndes sällan ungdomarna av de yrkesverksamma, än mer sällan omtalades de som konkreta personer. I en effektutvärdering av projektet, som en annan forskargrupp utförde, relateras hur samordnare kunde uppfatta ett misslyckat ärende: det handlade om hur samordnaren upplevt att hon inte fått gehör när hon kallat till möten med socialtjänsten. Hennes "ärende" definierades som misslyckat trots att det gick bra för ungdomen (Andersson, Lundström och Sallnäs 2010:76). Även ungdomarna vi intervjuade noterade den administrativa hållningen; en av dem förklarade exempelvis att samordnare är sådana som "skickar blanketter och sånt".

I denna artikel diskuteras hur möteskulturen gestaltar sig när den formeras som ett alternativ till mer personnära "care workers", dvs. en form av "vikarierande föräldragestalter", som visat sig vara betydelsefulla i ungdomsvård (Stein 2006, Degner och Henriksen 2007).

Analysen av möteskulturen har inspirerats av klassiker som Webers analys av byråkrati och Simmels analys av konflikter samt moderna samhällsvetare som ovan nämnda Perrows studie av organisationsamhället, Lipskys studie av närbyråkrater och Goff- mans dramaturgiska perspektiv. Framförallt har den amerikanska antropologen Schwartzmans bok The Meeting, (1989) där det moderna livets utbredda möteskultur uppmärksammas, varit användbar. Hon vänder på det till synes självklara sättet att betrakta dessa sammankomster. Möten associeras ofta till dessas manifesta funktioner: de är till, tänker vi oss, för att fatta gemensamma beslut, förhandla eller lösa problem. Istället visar Schwartzman via ett etnografiskt fältarbete hur möten kan genereras av rutin, det moderna livets ritualer, för att formulera (istället för att lösa) problem. Hon noterar också hur organisationer eller grupper via formella möten konstituerar och presenterar sig som specifika entiteter i förhållande till både sig själva och andra.

\section{Bakgrund}

Enligt ett regeringsbeslut 2006-06-29 fick Statens institutionsstyrelse i uppdrag att pröva en förstärkt vårdkedja inom ungdomsvården. Projektet: "Motverka våld och gäng" (av de involverade senare refererat till som MVG-projektet), tilldelades 230 miljoner kronor. Syftet var att förbättra situationen för ungdomar vars kriminalitet eller missbruk uppfattats som allvarligt. Statens institutionsstyrelse skulle samverka med socialtjänsten i de femton kommuner som ingick i försöksverksamheten, som skulle förbättra samordningen av insatser mellan myndigheterna efter utskrivningen från institutionerna. Den valda behandlingsmodellen skulle inledas med en vistelse vid särskilda ungdomshem för ungdomen; plat- 
ser där kommunen erhöll 40 procent rabatt inom projektets ram. Ett viktigt inslag i modellen var samordnaren som skulle "utgöra ett stöd för den unge, samt vara en länk mellan den unge, socialtjänsten och institutionen".

Bakgrunden till projektet var de brister som uppmärksammats i den nuvarande behandlingen. Efter tiden på ungdomshemmet återvänder ungdomarna inte sällan till en situation, liknande den som antogs orsaka att man hamnat i samhällsvård (Sluten ungdomsvård 2002:120). Ett annat, relativt typiskt drag i dagens behandlingssituation är att en rad myndigheter och aktörer är engagerade i ungdomarna. Gunvor Andersson (1999) tecknar en bild av en "institutionsvandring" för samhällsomhändertagna barn och ungdomar. $\mathrm{Nu}$ skulle man med vårdkedjan och dess samordnare försöka bryta denna vandring.

Två utvärderingar var knutna till projektet; en processutvärdering, som denna studie bygger på och en effektutvärdering (Andersson et al. 2010).

\section{Glidningen mot administrativa uppgifter}

Samordnarna skulle fungera som en underlättande hjälp för ungdomarna i vårdkedjan. De skulle se till att eftervårdsplaner konkretiserades: att skolplaceringar, frivårdsplatser, praktikplatser och så vidare fanns tillgängliga vid utskrivningen från Statens institutionsstyrelses ungdomshem. Under denna process skulle de fånga upp ungdomarnas och föräldrarnas erfarenheter, möjligheter och önskemål.
De involverade beskrev i projektets inledning samordnarna som "ungdomens och familjens språkrör". De retoriska former varvid projektet presenterades för omvärlden underströk också de individuella ungdomarnas centrala position $\mathrm{i}$ verksamheten. Personliga berättelser och närbilder i myndighetens tidning, som i artikeln "Jakobs samordnare gör så allting flyter" (SiS i Fokus, 2008, nr 1) samt i projektledarens beskrivningar till forskare och andra utomstående namngavs exempelvis ungdomar (medan man senare oftare hänvisade till klienter eller ärenden). Man berättade målande och illustrativt om enskilda ungdomar, deras hemmiljö eller vardagliga angelägenheter på institutionerna.

Så småningom kom betydelsen av kontakterna med ungdomarna och föräldrarna att tonas ner; samordnarna blev istället mer av en länk i den mötesverklighet som illustrerades genom projektet. Samordnarna var närvarande på olika möten, de var ibland sammankallande, ibland ordförande. Som ordförande skulle samordnarna med hjälp av "frågans makt" kunna aktualisera planer, problem eller beslut, som var angelägna för ungdomarna.

Förändringen mot en mer administrativ hållning avspeglades i språkbruket. Medan man inledningsvis refererade till "ungdomssamordnare" talade man efter hand endast om "samordnare". Utvecklingen sammanfattades av en samordnare som ett resultat av överläggningar, som skett över tid: "vi kom efter mycket diskussioner att enas kring att testa en metod, som handlade om en administrativ samordning". En samordnare som drev denna linje förklarade att vi skall inte vara "en extra kontaktperson" 
för ungdomen. Istället skall vi, menade hon, "säkra vårdkedjan" genom planering och beslut som fattas av och mellan de professionella. Några samordnare beklagade utvecklingen där man "tappat ungdomsperspektivet".

\section{Vårdkedjans mötesdeltagare}

Vårdkedjeprojektet producerade ett stort antal möten på olika nivåer. Till referensgruppsmöten och lokala arbetsgruppsmöten kallades institutionschefer, enhetschefer inom socialtjänsten, förste samordnaren från varje ort och projektledning. I andra möten deltog de som var fokus för projektet: ungdomarna. Dessa möten avsåg behandlingen vilken sågs i en linjär form, vilket illustrerades av termer som planeringsmöte, mittmöte och uppföljningsmöte.

Under möten som direkt berörde ungdomarna fanns en mängd yrkeskategorier knutna, även om inte samtliga var representerade vid samma möten. Fältanteckningarna nämner socialsekreterare, kontaktpersoner från institutionerna, intensivstödjare, drogterapeut, socialrådgivare, coach, lärare, familjeterapeut, psykolog, hemterapeut, skolkurator, familjehemsrepresentanter så väl som personal från öppenvård med namn som Vägvalet och samordnare. Eftersom många, såväl ungdomar som de professionella, har noterat att det är många yrkesrepresentanter som är involverade kring ungdomarna räknade vi hur många som framträdde under olika möten. Det visade sig att under de tjugoåtta möten vi observerade där ungdomar var med, deltog i genomsnitt sex professionella. Dessutom var ofta någon eller några familjemedlemmar närvarande.

\section{Material och metod}

Eftersom vår ambition var att följa vårdkedjan och framförallt samordnarnas arbete utgjorde utvärderingen ett intensivt och arbetskrävande företag, som varade under tre år (2006-2009). Flera forskare, framförallt författarens medarbetare, samt två studenter utförde ett stort antal intervjuer och fältobservationer (Basic et al. 2009) då ungdomarna var institutionsplacerade på många olika platser i landet och skulle följas upp av samordnarna vid förflyttningar och utskrivningar. Därtill skulle möten mellan för ungdomsvården relevanta yrkeskategorier samt föräldrar bevakas.

Konkret grundar sig studien på flera olika sorters empiriska material: i huvudsak samtalsintervjuer och fältobservationer. Skilda situationer som bevakats har nedtecknats i fältanteckningar. Dessa beskrivna situationer kunde röra sig om organiserade möten i projektet men också mer informella sammankomster före och efter intervjuer eller sammanträden, besök på institutioner, på samordnarnas arbetsplatser och liknande.

Kvantitativt innefattar vårt material följande intervjuer och fältobservationer:

Antal intervjuer:

Ungdomar:

Föräldrar:

Samordnare: 
Socialtjänstpersonal:

(varav 13 enhetschefer samt 26 soc.sekr.)

Institutionspersonal:

Antal observationstillfällen av:

Samordnarnas arbete

Referens- och arbetsgruppsmöten:

10

Intervjuerna har varit av samtalskaraktär, så kallade "aktiva intervjuer", där intervjuaren uppträder i rollen som samtalspartner snarare än utfrågare (jfr Holstein och Gubrium 1998). Intervjuerna har varat mellan 30 och 90 minuter; de flesta i cirka en timme. Intervjuerna, som till stor del utförts av Goran Basic, har spelats in på band och sedan transkriberats. Huvuddelen transkriberades av forskarna men några transkriberades även av en student. Fältanteckningar har nedtecknats noggrant och sammanställts i enlighet med etnografisk tradition både på plats och i efterhand (Emerson et al. 1995). De fältanteckningar som relateras här härrör från en och samma observatör, Joakim Thelander. Samtliga deltagare har anonymiserats och givit sitt samtycke till att delta i undersökningen.

Forskargruppens medlemmar träffades kontinuerligt för att jämföra fältanteckningar och söka säkerställa att vi fokuserade på liknande frågor och fenomen. Vi höll också gemensamma seminarier med representanter för effektutvärderingens forskargrupp.

Materialet har analyserats kvalitativt med inspiration av ett interaktionistiskt perspektiv och där det diskursiva inslaget varit tongivande (se Holstein och Gubrium 2003). Samordnarnas uppgifter präglades av en mångfald diskursiva benämningar, de vårdade ungdomarna framträdde ibland som personer men oftare som "ärenden" eller "klienter" och möten gavs olika beteckningar. Samtidigt är benämningarna sammanfogade och inbundna $i$ interaktionen med de samspelande parterna, liksom i den övergripande kulturen och de professionella lokala kulturerna.

Denna artikels tema framkom då artikelförfattaren fördjupade sig i fältanteckningar och tillhör alltså inte utvärderingsstudien per se. Kvalitativt material är ofta så rikt att det lämpar sig för nya undersökningar där man applicerar ett delvis nytt perspektiv (Åkerström, Jacobsson och Wästerfors 2007).

\section{Möten: benämningar och möteskedjor}

Möten, i betydelsen formella samspel med bestämda tider och representanter för olika yrkeskategorier och/eller organisationer, framstod som samordnarnas främsta arbetsarena. När Erving Goffman (1967) skrev: "Where the Action is" exemplifierar han med dramatiska, lätt ödesmättade aktiviteter som spel etc., där det finns möjlighet att pröva sina egenskaper, sin moraliska karaktär och kompetens. Frågan är om mötet uppfattas som just sådana prövningar för dedicerade administratörer. Samordnarna skulle ha kontakt med ungdomar och föräldrar, men också närvara på för dessa kategorier viktiga möten. Formellt sett var mötesnärvaron angiven. I dokumentet Samordnarrollen inom Värdkedjeprojekt ungdom - MVG, slås fast: "Mötet är samordnarnas viktigaste forum". I en 
mycket mer grundläggande mening tycktes emellertid möten varit samordnarnas hemvist: en arena för att utarbeta sin yrkesroll.

Mötet framstod i våra intervjuer och fältobservationer som ett heligt objekt (Collins 2004), ingen ifrågasatte dessa, ingen behövde närmare förklara sig om man kom för sent. Det räckte med att kort meddela att man varit på ett "möte". "Mötet" var själv-legitimerande. ${ }^{1}$

Mötet som ett heligt objekt tydliggörs i dess rituella form. Vi urskilde dessa möten i projektet när samma personer samlades $i$ väntrum eller till luncher, då samtalet inte behandlade de ämnen som var avsatta för Mötet.

Inför mötet småpratar man om annat som väder och vind. Hälsningsceremonier genomförs, man nickar, tar i hand eller kramas. När man stiger i in möteslokalen understryker tröskeln en lokal, situationell rite de passage; det ceremoniella understryks också interaktionsmässigt då alla sätter sig, harklar sig, vissa tystnar, tittar igenom sina papper. Det formella mötet inleds då alla samlats och man fokuserar på någon som är ordförande, eller då denne/a tar befälet och inleder med något ord som "välkomna" eller"Ja, då ska vi prata om ..."

Samspelet förutsätter med andra ord en kulturellt kodad kunskap för att kunna urskilja dessa mötesindelningar. Detta har också de engelska forskarna Atkinson, Cuff och Leer (1978) påpekat i en studie som visat hur möten initieras då man avbrutit

1 Ett liknande resonemang återfinns i Harnetts (2010) studier från äldreboenden där rutiner framträder som verksamhetens heliga objekt som ingen ifrågasätter. för en kaffepaus. När och hur skall det riktiga mötet inledas? I deras fall användes det engelska "Right-er" som en inledning för att fånga och fokusera deltagarnas uppmärksamhet. Scenen och rollerna hjälper till: det är ordföranden som yttrar" right-er".

Sådana inledande småord eller markeringar markerar början på ett mer formellt, disciplinerat tal där man håller sig till dagordning eller vissa teman, om en formell dagordning inte finns. Till det formella mötet hör också en speciell ton och en professionell vokabulär. Vid avslutningen tackas de medverkande, deltagarna tar upp sina kalendrar för att boka ett nytt möte. Sedan samlas papper samman, man skakar hand, säger hej, vinkar. Efter detta återupptas ett mindre formellt och fokuserat samtal om väder och vind, sjukdomar, korta meddelanden om vart man är på väg eller vilka aktiviteter som planeras.

De formella möten som förekom inom projektets ram, har undersökts genom en redogörelse för hur deltagarna själva refererar till dessa.

\section{Projektets mötesindelningar}

En sådan utforskande strategi som Schwartzman (1989) föreslagit kring möten per se kan illustrera vilka möten som förekommer i fältobservationer och intervjuer. Det visar sig att det handlar om ett relativt stort antal möten som särskiljs eller som refereras till. Att det som är en kulturell angelägenhet ges många benämningar är en etablerad etnografisk observation, beträffande allt från ris (Hanunóofolkets har 92 varianter av benämningar på risvari- 
anter; se Brown 1965) till taxonomier kring narkotikamissbrukares vokabulär (Agar, 1994:73-88). I denna undersökning relaterades och separerades möten på följande sätt av de involverade:

Olika typer av möten:

\begin{tabular}{|l|l|}
\hline Arbetsgruppsmöte & Extramöte \\
\hline Förmiddagsmöte & Förmöte \\
\hline Gruppmöte & Informationsmöte \\
\hline Inskrivningsmöte & $\begin{array}{l}\text { Lokala arbets- } \\
\text { gruppsmöten }\end{array}$ \\
\hline Mittmöte & Nätverksmöte \\
\hline Personalmöte & Planeringsmöte \\
\hline $\begin{array}{l}\text { Referensgrupp- } \\
\text { smöte }\end{array}$ & $\begin{array}{l}\text { Rekommendations- } \\
\text { möte }\end{array}$ \\
\hline $\begin{array}{l}\text { Samordna samord- } \\
\text { narmöte }\end{array}$ & \begin{tabular}{l} 
Skolmöte \\
\hline "Soc-möte"
\end{tabular} Teammöte \\
\hline Telefonmöte & Uppdragsmöte \\
\hline Uppföljningsmöte & Veckomöte \\
\hline Videomöte & Överlämningsmöte \\
\hline
\end{tabular}

Förutom dessa möten återfinns i vårt material:

Möten som refererar till varandra:

Förra mötet

Föregående möten

Nästa möte

Kommande möten

Möten som referenser till olika kategorier av människor:

Möte med socialtjänst

Möte med föräldrar

Osv.

Gamla och nya former:

Videomöten skiljs från "vanliga möten"
Sammanbindningsord, som pekar på plats samt tid och rytm:

Möteslokaler och mötesrum

Mötestäthet, mötesfrekvens och mötestider

Förutom dessa möten, som angivits ovan, arrangerades ett antal återkommande konferenser som enbart samlade yrkesverksamma och myndighetsrepresentanter. Ovanstående listade möten är dem som refererades till i projektet av de involverade, med en etnometodologisk terminologi "medlemmarnas möten". Vissa av dessa redovisade möten inbegrep ungdomarna, under andra möttes enbart yrkesverksamma (exempelvis "teammötet", där signifikant nog inte ungdomarna eller föräldrarna ingick utan var beteckningen på de lokala samordnarnas möten).

\section{Möteskedjor}

Både eftermöten och förmöten utgör ett slags möteskedjor då dessa möten refererar till varandra, varvid besluten, diskussionen, konflikterna - kan användas för att föreslå nya möten.

På ett formellt plan var ungdomsvårdsprojektet uppbyggt i en byråkratisk kedjeform. Samordnarna kunde exempelvis diskutera frågor som härrörde från den egna gruppen, som skulle föras vidare till en lokal arbetsgrupp eller referensgrupp och så småningom kunde samordnarna i de egna mötena referera tillbaka till den byråkratiska beslutshierarkin: "på referensgruppens möte har vi fått mandat att .... Själva behandlingen av de unga var också strukturerad i en tidsmässig form, där det ena 
mötet skulle gripa tag i det förra och förbereda inför nästa: akutmöte, intagningsmöte, planering, mittmöte, avslutningsmöte, överlämningsmöte. De olika mötena skulle följa upp det som sagts tidigare och planera framåt inför nästa möte.

Parallellt med den formaliserade ordningen fanns emellertid en mötenas egendynamik. Nya möten kunde genereras då man träffades vid de redan institutionaliserade schemalagda sammankomsterna. Efter ett inbokat utredningsmöte på en institution pratar samordnaren med socialsekreteraren. "De kommer överens om att man bör träffas snart och göra en planering för den fortsatta tiden tillsammans med Q. så att det blir tydligt för honom vad som ska hända." (Fältanteckning). Här hänvisar samordnaren eller socialsekreteraren alltså inte till redan fastlagda sammankomster.

En annan typ av egendynamik utgörs av för- och eftermöten.

\section{Möten om möten}

Efter det att ett möte hållits förekommer inte sällan "post-meeting" där "mötet" som nu har objektifierats kan ventileras (Schwartzman, 1989:137). Ofta hålls dessa informellt i mindre grupper.

Även i detta projekt genererades möten av andra möten. Detta skedde efter varje möte, om tid och möjligheter till interaktion fanns. De i gruppen som stannade kvar samlades för att informellt dryfta det mötet resulterat i-eller inte resulterat i.

Ibland ägnades även formella möten åt ett tidigare möte. Detta gällde särskilt möten, som inte var så strikt arrangerade med dagordning mm. Så var exempelvis fallet en arbetsdag då samordnarna har ett team-möte:

Förmiddagens möte med socialtjänsten avhandlas under största delen av tiden. Det gick inte särskilt bra anser man, vad kan vi förtydliga? Varför är de negativa? Sedan diskuteras även kommande möten. Ska man vara med på planeringsmöte? Vissa institutioners behandlingsmöten utvärderas och man varnar varandra: På Stjärnhult är de segare än gammalt tuggummi ... "Sả boka inte in något annat samma dag om ni har möte där". (Fältanteckning)

Möten hölls inte enbart efter ett annat möte, även "förmöten" förekom, vilket vi ser spår av från fältanteckningarna ovan. Teammötet förvandlas i någon mån till förmöte i den mening att samordnarteamet resonerar kring hur man skall ställa sig till andra möten, planeringsmöten och behandlingsmöten - och en institutions tidsmässiga hantering av möten diskuteras.

I allmänhet handlar förmöten om att förbereda en viss linje eller argumentation. Det klassiska förmötet bygger upp en allians eller agenda inför ett kommande möte. Sådana allianser kunde emellertid vara känsliga, därför är inte sällan förmöten dolda för vissa av deltagarna på det stundande mötet. I ett fall befarar man att ett synligt förmöte kan innebära problem. En samordnare berättar vid en fältobservation om att hon har ett möte med en socialsekreterare under förmiddagen beträffande en pojke som har en "svårmotiverad mamma":

Vi pratade om att jag och socialsekretera- 
ren kanske tillsammans skulle prata med henne. Men det finns en risk med det, och det är att om jag kommer tillsammans med socialsekreteraren så kan det uppfattas som att jag också tillhör socialtjänsten.

Förmöten med socialtjänsten kan emellertid ibland kommenteras som rimliga och oproblematiska. Under ett möte inom samordnargruppen i projektets inledande fas diskuteras socialtjänstens skeptiska hållning. En sektionschef från socialtjänsten har väckt frågan om hur oenighet mellan socialsekreterare och samordnare ska hanteras. Samordnaren hade svarat de inte ska driva någon linje, de ska finnas med på möten för att kunna ställa frågor. (Här hänvisar de till projektmodellen där samordnaren skall vara ordförande på möten och med "frågans makt" aktualisera förbisedda områden). I samordnargruppen enas man nu om att problemet med potentiella tvister skall lösas genom förmöten med socialsekreterarna. Att ställa oförberedda frågor under ett möte är "inte relationsskapande".

Man pratar också om vikten av att kommunicera med socialsekreterare före mötena, Tomas (samordnare) menar att Ingela (från socialtjänsten) under förra mötet hade en poäng när hon menade att vissa frågor kan ställa socialsekreteraren $i$ dålig dager. "Frågans makt" under själva mötena är inte relationsskapande med soc. säger Tomas, och han fortsätter: "Vi bör inte ta upp en stor, ny fråga vid ett möte utan att prata med socialen om det först". De andra häller med, och menar att frägor under mötena kan ha funktionen att göra det tydligare för den unge vad som händer, det är då frägor som man frän institutionen och soc. redan har svaret på. (Fältanteckning)

Användningen av "frågans makt" var ursprungligen avsett att ge samordnarna möjlighet att strukturera olika yrkesrepresentanters insatser (att "lyfta" glömda eller förbisedda frågor eller åtgärder). I samordnarnas diskussion blir istället "frågans makt" en möjlighet att "tydliggöra för den unge vad som händer": "frågor som man från institutionen och soc. redan har svaret på". Det problematiska i ett sådant upplägg diskuteras inte, nämligen att ungdomarna skulle vara delaktiga i planering och behandling.

Förmöten och eftermöten integreras inte sällan; det ena leder till det andra. Dels kan det innebära att man bestämmer sig för ett nytt, separat möte, vid sidan av det möte, som förmötet skulle förbereda, dels kan ett och samma möte ha båda ingredienserna. Så var exempelvis fallet när en samordnare bestämt tid med en socialsekreterare efter ett möte på en institution. Utredningssekreteraren hade under sammankomsten "känt sig överkörd" och nu ville samordnaren prata med socialsekreteraren så att det fungerar bättre nästa gång. "Eftermötet" utvecklas emellertid också till ett förmöte i det att man förbereder det som skall sägas vid nästa möte. Samordnaren noterar att:

Hon har läst $i A D A D^{2}$ att den unge anser sig

2 Ett utvärderings- och dokumentationssystem som Statens institutionsstyrelse använder sig av. ADAD är uppbyggt av intervjuer med ungdomarna vid inskrivning, utskrivning och efter behandling. 
ha syn- och hörselproblem, något som inte diskuterades senast och som samordnaren tycker är viktigt att ta upp vid nästa möte. 'Det kan ju vara det som ställer till det med hans skolgaing, viktigt att få klarhet $i$ det'... Det där tänker jag ställa frågor om under mötet, är det OK? (Fältanteckning)

Framtida medaktörer förbereds så att de inte ska spoliera nästa framträdande samordnaren försöker i detta fall involvera socialsekreteraren så att hon inte motarbetar samordnarens förslag; hon förbereder marken för ett gemensamt teamarbete vid den framtida sammankomsten (jfr Goffman 1974).

\section{Involverande möten}

Den amerikanska antropologen Helene Schwartzman, som tidigare refererades till, skriver om möten generellt, men inspirerades av sitt etnografiska fältarbete på en amerikansk alternativ sjukvårdsorganisation för mentalsjuka, "Midwest". Deltagarna i denna uppvisade, skriver hon, ett stort engagemang i sina möten (1989:159). Något annat var inte möjligt i denna mötestäta organisation, som skulle vara ett alternativ till den mer centraliserade och institutionaliserade vården.

På samma sätt var de möten som förekom och delvis genererades via det ungdomsvårdsprojekt vi undersökte, starkt involverande. Närbyråkrater arbetar ofta i yrken som har motstridiga eller ambivalenta syften påpekar Lipsky i sin moderna klassiker Street-Level Bureaucracy (1980:40). Det här studerade projektet tydliggör spän- ningen mellan att vara "ungdomens röst" och "vårdkedjans kvalitetssäkring”. Konflikten mellan den administrativa hållningen och det som kallades ett ungdomsperspektiv (att vara ungdomens språkrör och därför hålla kontakt med dem), var emellertid inte särskilt framträdande i intervjuerna med de yrkesverksamma. Närbyråkrater har, som Lipsky (1980) poängterat, ett relativt stort handlingsutrymme. I det här undersökta projektet valde samordnarna att använda sin tid till möten, utformning av dokument och samspel med andra professionella istället för att interagera mer tätt med ungdomarna och deras föräldrar Denna administrativa hållning avspeglas inte som en neutral inställning utan som ett starkt engagemang. Engagemanget illustreras på en rad punkter, vilka skall återges nedan.

\section{Arbetsdagens mål och mening}

En tjänstemans arbetsdag består av många delar: samtal, rapportering, och inläsning av dokument men för samordnarna är det de möten man har under dagen, som tycks vara det som definierar yrkesrollen, som strukturerar och sätter fokus på arbetsdagen. Möten ger en möjlighet att uppvisa aktivitet och de definierar en händelserik arbetsdag. Även hållningen till en avsaknad av möten visar på uppfattningen att dessa är samordnarnas arbetsarena par excellence. Vid ett besök på en av huvudorterna noteras förmiddagen som "händelselös" därför att möten blivit inställda. En av samordnarna, Lotta, ursäktar bristen på något 
att observera eller medverka i; vid nästa besök utlovas "lite mer aktivitet":

Lotta säger att jag haft lite otur. På grund av att ett par möten blivit inställda och flyttade så har just den här veckan varit ovanligt lugn för deras del. Vi kommer överens om att försöka ordna så att jag fär se lite mer aktivitet när jag besöker dem igen till hösten. (Fältanteckning)

En annan indikation på hur medlemmarna i en yrkeskategori definierar arbetets kärna kan återfinnas i det sätt varvid de kvantifierar det de berättar om. En lärare kan berätta om hur många klasser han haft och en arkitekt hur många hus han ritat. Samordnarna markerade och mätte ut sitt arbete i ärenden, men också i möten. När man vid en samordnarträff vid något tillfälle klagade över arbetsbelastningen är det antalet ärenden man är bekymrad över (först skulle man ha 15 ärenden, sedan blev det 20). Sättet man föreslår att hantera arbetsbelastningen på, handlar om att minska och "glesa ut" de möten man bevakar.

Elisabet säger att en variant att minska arbetsbelastningen är att glesa ut: "Man behöver kanske inte vara med på mötena var sjätte vecka, utan kan vara med var tredje månad om det fungerar". --- Annika har dock en invändning. Hon säger att en tanke med samordnarskapet var kontinuiteten för den unge, och hur går det med den? Elisabet svarar att det bara blir aktuellt att glesa ut om det fungerar med planeringen. (Fältanteckningar)
Flera undersökningar visar att många yrkesverksamma uppfattar möten som tidsslöseri; slöseri därför att de ses som urholkande av den tid man vill ägna åt det som betraktas som yrkets kärna. I studier av yrken som har med människor och människors förändring att göra finns ett antal exempel. Den amerikanska forskaren Mansbridge (1983) visar exempelvis hur en s.k. alternativ rådgivande hjälporganisation "Helpline", som styrdes genom direktdemokrati, valde nya former när de anställda och frivilligarbetarna började uppfatta mötesverksamheten som alltför betungande.

En stor forskningsöversikt av företagsvärlden visar att tidsåtgången för chefer och arbetsledare har sedan 1960talet, något som dessa uppfattar som ett problem: "meetings suffer from a myriad of problems, making managers and workers alike dissatisfied with the process and the outcomes in many cases" (Romano och Nunamaker, 2001:11). Chefer och arbetsledare tillbringar exempelvis mer tid i möten än i aktiviteter de själva säger sig vilja ägna sig åt, som planering eller strategiskt tänkande.

Även Schwartzmans genomgång av liknande tidigare studier, visar att många snarare "står ut" med möten än uppskattar dem (1989:55-57). ${ }^{3}$

Sammantaget kan man alltså inte förvänta sig att människor ska omfamna möten med entusiasm. Den bild vi får av de yrkes-

3 Hennes kartläggning av tidigare studier visar emellertid också att en del tjänstemän uppskattar möten i det att dessa ger möjligheter till förhandlingar, är informativa samt ger tillfällen till att locka fram ny information. 
verksamma deltagarna i projektet är emellertid inte den motvilliga och distanserade. Möten ses som nödvändiga och självklara. Vi hittar inte särskilt mycket av klagomål, irritation eller definitioner av möten som onödig tidspillan. Möten är samordnarnas arbetsarena.

\section{Mötesrecensioner}

Engagemanget i det som händer under mötet ger avtryck i de yrkesverksammas utvärderingar. De deltagande hänger sig åt bedömningar: var det ett bra eller dåligt möte? Mötesrecensioner handlar i allmänhet om andra professionellas insatser, inte om ungdomarna. De som i huvudsak figurerar i samtalen är socialsekreterarna, behandlingspersonal eller annan vård- eller pedagogisk personal.

Vi kan se hur de professionella bedömer varandra när en utvärdering med uppskattande inslag gjordes efter en träff på ett ungdomshem. Föräldrarna har varit med och på mötet har det beslutats om en familjehemsplacering, efter det att pojken skrivs ut från institutionen.

Efter mötet pratar Stefan med socialsekreteraren. De tycker båda att mötet gick bra ... Stefan och jag sätter oss $i$ bilen och kör till Stockberg. Han är verkligen nöjd med socialsekreteraren: "Hon är jättebra, helt med påbanan". (Fältanteckning)

Stefan, som är samordnare, är nöjd. Det är dock svårt utifrån fältanteckningarna att riktigt veta vad samordnaren är nöjd med: om det är formen av placering - eller om det är själva samspelet med de andra parterna som fungerat väl. Hans kommentar gäller socialarbetaren, som är "helt med på banan". Ungdomen är emellertid inte riktigt "med på banan", men det är forskaren i det här fallet som kommenterar pojken, Alis, tveksamhet och för in honom i samtalet.

Jag säger att jag tyckte Ali verkade tveksam till planerna. "Det är knepigt här, han vill egentligen hem men de vill inte ha honom hemma". "Ja, så därför var de nöjda med familjehemslösningen?", säger jag. (Fältanteckning)

Mötesdeltagarnas utvärderingar kan också vara kritiska. Efter ett möte med en mamma, en dotter och en socialsekreterare på socialförvaltningens kontor argumenterar samordnaren i ett samtal med utvärderaren intensivt mot socialsekreterarens sätt att sköta mötet. Socialsekreteraren, anser hon, har inte följt den tänkta modellen: flera delansvariga representanter som skulle medverkat har inte gjort det:

Annika och jag följs åt ut från kontoret, stiger ut $i$ vairsolen. Jag frägar vad hon tyckte om mötet: "Jag blir så trött att jag fär lust att sätta mig ner här på trappan". Hon fortsätter: "Hon [socialsekretaren] gjorde alla fel man kan göra, det här var så långt från idealet som man kan komma". Jag frågar vad hon tänker på. "Ja, var fanns VIKA-personalen ${ }^{4}$, till exempel? Var fanns läraren? Skolan är ju jätteviktig i detta. Och

4 VIKA är en påhittad akronym, men avsåg ett frivårdsprogram. 
det är inte klart med resurspersonen heller. (Fältanteckning)

Ett möte genererar inte sällan flera utvärderingar - beroende på vilken publik man har, dvs. med vem man samspelar. Här har samordnaren varit på en sammankomst benämnd "Nätverksmöte 2". Den första utvärderingen involverar samordnaren, socialsekreteraren och en lärare. Här framförs kritiken lite försiktigt. Den deltagande fältobservatören noterar:

Efter mötet blir det lite "eftersnack" i köket. Berit, läraren och Annika (samordnaren) pratar, jag står med och lyssnar. --- Jag får intrycket att varken Annika eller Berit fullt ut tror på lösningen med hemterapeuten. (Fältanteckning)

I en andra utvärdering är det Joakim, som skrivit fältanteckningar, som agerar publik. Samordnaren tycks känna sig fri att mer rättframt uttrycka tvivel på socialtjänstens insats och förklarar detta mer frankt: "Det har inte fungerat innan, så varför skulle det fungera nu? Familjen har redan provat hemterapeuten och trivs inte med henne". (Fältanteckning)

Bedömningar kring möten handlar inte enbart om utvärderingar av åtgärder; de kan också handla om det mer eller mindre lustfyllda. Framförallt vid inledningen av projekttiden mötte samordnarna ett starkt motstånd från socialtjänstens representanter inför den egna yrkesrollen. Dessa startsvårigheter diskuteras nedan, men man avslutar med att man uppskattar "att komma igång".

Erica: ---- Jag tycker det var skitkul att va på socialtjänsten och träffa socialsekreterare och ser fram mot dom flesta föräldrar och ungdomar jag har. Dom mötena tycker jag är skitkul ---

Johanna: Jag känner att jag går igång nu när jag fär börja jobba i samtal och komma ut och träffa ungdomar och föräldrar igen, då bara vänta "det är det här som är jävla roligt". Inte bara sitta med negativa socialsekreterare som bara säger "näh häh". (Gruppintervju med samordnare)

Den ena samordnaren uppskattar att "va på socialtjänsten", medan hon infogar en liten reservation för möten med ungdomarna och föräldrarna: "de flesta" möten med dessa kategorier kvalificerar sig för en positiv värdering. Den andra samordnaren, Johanna, anger istället att möten med ungdomar och föräldrar är de som är "jävla roligt". För henne är det möten med socialarbetarna som är icke eftersträvansvärda. Hennes kommentar kan ses som en introduktion till nästa avsnitt, som kort behandlar de strider som fördes innan, under och efter möten.

\section{Möteskampen}

Simmel skrev i sitt klassika arbete Kamp (1970/1908) att striden inte handlar om att parterna inte bryr sig om varandra: tvärtom indikerar kampen ett engagemang. På detta område ser vi professionella, som representerar olika yrken, olika myndigheter som verkar i samma fält engagerade i en ibland intensiv strid.

Vårdkedjeprojektet involverade representanter för olika myndigheter samt en ny yrkeskategori (samordnarna), som skulle 
samarbeta kring hur de institutionsplacerade ungdomarna skulle hanteras. En sådan samverkan innefattar nya rutiner och förändrade maktrelationer, vilket bäddar för motsättningar av skilda slag. Forskare inom fältet "Interorganizational Relations" har också noterat:

It is perhaps not surprising that the wielding of power, which can be characterized as the ability to influence, control, or resist the activities of others, arises as an issue in the context of many varieties of research in inter-organizational relations. (Huxham och Beech 2008: 555).

Eftersom samverkan mellan organisationer ofta hanteras via möten och sammankomster är det naturligt att en sådan maktfråga handlar om möteskampen.

Maktkampen i det här studerade projektet kunde handla om formalia: vem som fick vara ordförande, vem som skulle besluta om dagordning, vem som skulle skriva protokoll osv.

Det handlade också om en kamp om makten till och på mötet. Möteskampen innebar således en rad analytiskt åtskiljbara strider. Makten till möten innefattade en strid om att få komma till möten, bli inbjuden eller bestämma tider. Ibland berättar samordnarna om att socialtjänstanställda hänvisar till direktiv man fått om att inte ta hänsyn till samordnarnas önskemål:

... eee jag vet att vi har haft problem med en stadsdel där jag hade ett ärende där man har inställning som en socialsekreterare säger "vi har för farao att vi ska inte ta hänsyn till er" när, vi kan ta, vi bokar tider med institutioner eller på möten och mötena är vårat liksom viktigaste forum för vair del. Och det blir svairt när deras inställning är så tydlig för det innebär också att, att man tar ingen hänsyn när jag säger "när ni bokar tider kan ni tänka er tittapå de här dagarna dåjag inte är bokad" då fär jag mail tillbaka "vi har fätt direktivet att inte ta till hänsyn till er". (Intervju med samordnare)

Makten på eller under möten innefattade socialpsykologiska strider såsom Johan Asplund (1987) beskrivit dem eller de retoriska strider som Katarina Jacobsson (2000) analyserat. Jacobsson undersöker hur medlemmarna i den svenska dövvärldens olika falanger föregriper och bemöter varandras kritik genom skilda argument, berättelser och metaforer. Asplund resonerar kring makt som är episodisk och utövas ansikte mot ansikte av individuella aktörer. "Det karakteristiska för den mest elementära makten är att den blir utagerad i konkreta situationer" (1987:14-15). Asplund använder subtila exempel, som att medvetet avstå från att besvara en hälsning.

Genom småfrågor eller anmärkningar under projektets gång kunde konflikterna skönjas. Socialsekreterarna återgav kritiska kommentarer i intervjuer, vissa ansåg exempelvis att samordnarna komplicerat deras arbete genom att de tillfört svårigheter att koordinera sina vanliga mötesrutiner. Vissa ansåg också att den nya yrkeskategorin, samordnarna, var onödig. Ibland kommer sådana synpunkter fram även när medlemmarna träffar varandra. Ett exempel gavs mot slutet av en sammankomst när nya möten skulle planeras. När Annika, som är samordnare, vill koordinera alla involverade 
(lärare, hemterapeuter, resurspersoner, personal från ett behandlingsprogram) för att spara tid, svarar socialsekreteraren:

"Måste du vara med på alla möten, då?" och Annika säger att det bör hon vara eftersom hennes uppdrag är att ha fokus på eftervården. Hon vänder sig till mig och säger något i stil med att "så är det väl?" och jag säger att så har jag också uppfattat det. (Fältanteckning)

"Måste du vara med på alla möten, då?" Nödvändigheten av samordnarens närvaro på möten betvivlas. Formuleringen är ifrågasättande, men inte öppet konfrontatorisk. För att lösa situationen tar samordnaren hjälp av utvärderaren - en expertroll vi erhöll ibland, för att få stöd för sin definition av anställningens plikter. Ett ännu tydligare ifrågasättande uttalas i samband med ett uppföljningsmöte med Valet, en öppenvårdsverksamhet i en av storstäderna. Den unge pojken har varit något av ett projektets mönsterungdom, han har uppskattats av ungdomshemmets personal och har nu flera avklarade skolbetyg och dessutom utbildningsplaner. Han har skrivits ut men har vid något tillfälle druckit alkohol och rökt hasch. Förklaringen placeras i bristen på sysselsättning, hans kontaktperson säger: "Han avskyr att vakna varje dag i (förortens namn) i tomhet och inte ha något att göra, inget jobb, ingen skola." Situationen är fortfarande inte löst. Skolplaceringen och praktiken har inte realiserats. Anja från Familjebasen (en organisation som stadsdelen som förorten där han bor, driver) undrar då varför inget var klart när han kom hem och säger att "hon förstått att det ska MVG (pro- jektet) jobba med, just de sakerna."Samordnaren förklarar att Valet själva velat sköta kontakterna med skolan.

Möteskampen kunde också demonstreras genom ägandestrider, som avslöjas i formuleringar som "hennes möte" eller "mitt möte". Här fanns samordnare som kritiserade socialsekreterare för att vilja äga ett möte, men det fanns också de som kritiserade samordnare för samma sak. Eller, som här, en behandlingsassistent, som säger sig vara beredd att försvara sin rätt att äga mötet - han har ryktesvägen hört talas om att vissa samordnare gör anspråk på för mycket inflytande under behandlingskonferenser där de medverkar:

... men ryktet säger det (med hög röst), det finns några MVG-samordnare som gärna är med och för samtalen när det är behandlingskonferensen och min... vad jag har fätt tilldelad mig så är det att de ska sitta med, lyssna av, anteckna och givetvis göra som Tobias (en samordnare) komma med sma frägor. Men det är inte de som äger mötesrummet, det är jag som gör det eller socialsekreteraren. --- Om de kommer in och sätter sig i rummet och helt plötsligt äger mötet då är det så att jag kommer att ifrågasätta det. (Intervju med behandlingsassistent)

\section{Möteskonkurrens och uteblivna möten}

Någon knackar på dörren, Berit har ett annat möte som börjar nu. "Ni fär börja utan mig, jag kommer snart", säger hon till personen i dörren. (Socialsekretaren måste skynda sig att avsluta ett möte) 
Jag skulle gärna ha varit med på mötet med skolan imorgon, men det kan jag tyvärr inte. Men jag ska gå på mötet med VIKA på torsdag (Samordnaren kommenterar information hon just fätt på ett möte). (Fältanteckning)

Ovanstående kommentarer illustrerar den möteskonkurrens vi urskilde under studiens gång. Tidsåtgången för mötesverksamhet för chefer och arbetsledare har, som tidigare framgått, ökat drastiskt (Romano och Nunamaker 2001). En konsekvens av denna mötestäthet är att nya möten blir svåra att organisera då arbetsdagarna redan är intecknade för andra möten. I vårt material återfinner vi många exempel på deltagarnas problem att synkronisera sina kalendrar; framförallt då man vid slutet av ett möte skall finna tider för nästa möte. Slutet av en fältanteckning formuleras sålunda: "Det blir ett kort eftersnack, för klockan är 16 och ett annat möte väntar. Man enas med viss möda om en ny tid, fredagen den 5 juni kl. 10.00."

Efter sådana svårbestämda mötestider och med allt mer upptecknade almanackor försöker samordnarna ibland effektivisera mötesgrupperna: att samla alla involverade. Detta är emellertid inte alltid helt enkelt. Socialsekreterarna eller andra yrkesrepresentanter, som man sammanträder med, kan anse att även om ambitionen är bra, är det en svår uppgift att organisera - allas scheman måste då passas in. Här håller mötet på att avslutas:

... Ingrid (soc.sekr) summerar: "OK, till nästa möte ska S. komma--. OK?". Mamman säger att det är $\mathrm{OK}$. Helena (samordnare) säger att hon framöver gärna vill att de kan slå samman mötena lite bättre, för det ska vara ett möte angående S. med skolan snart och ytterligare ett med $A R T^{5}$. Ingrid häller med om att det är många möten, men menar att det är svårt att hitta tider som passar alla. Helena säger att hon förstår det, men att hon har många ärenden och har svårt att finna tid till alla möten redan som det är. (Fältanteckning)

En annan indikation på möteskonkurrensen är att trots att så många möten innefattar många professionella fattades inte sällan någon eller några deltagare - ofta förklaras deras uteblivande med ett kolliderande möte.

Men även vi som forskare och utvärderare upplevde svårigheter att få tillgång till de yrkesverksamma utanför avtalade mötestider. Inledningsvis tänkte vi oss att vi kunde fånga de verksamma i flykten, småprata lite då man ändå träffades i olika sammanhang eller passa på att genomföra en samtalsintervju. Detta var emellertid inte någon lyckad metod. Ett exempel på en situation efter ett behandlingsmöte:

Jag försöker prata lite med soc. om hur hon tycker att det funkar men hon är stressad: "Jag måste iväg nu, ska vara på ett annat möte klockan ett". Hon tittar på klockan. "Det blir ingen lunch idag", säger hon resignerat. (Fältanteckning)

Alla dessa fältanteckningar vittnar om en möteskonkurrens. Samtidigt fanns det ett

5 En behandlingsmetod där förkortningen står för Aggression Replacement Training. 
socialt tryck kring fler möten. På ett referensgruppsmöte klagar exempelvis en socialtjänstchef över att samordnarna inte varit synliga i hennes kommun. Hon efterlyser samordnarnas närvaro på ett referensgruppsmöte: 'Samordnarna i Hamberg är osynliga helt enkelt' och att man efterfrågar att samordnarna är mer ute i Hamberg och träffar socialsekreterarna."

\section{Diskussion}

I denna artikel har den administrativa hållningen diskuterats med särskilt fokus på en av dess ingredienser: mötesverksamheten. Den administrativa hållningen avspeglade sig också i det byråkratiska språket: refererandet till regelverk, till myndigheter, benämningar på dokument och i ett transformerande av ungdomar till "ärenden". Det hade varit möjligt att samordnarna i större utsträckning exemplifierade och belyste projektet via illustrationer av konkreta ungdomar - även om projektet inramades via möten och dokument. Istället är ungdomarna egendomligt frånvarande i samtal med de professionella. När de uppträder gör de det som könlösa och opersonliga ting; de faller i en "diskursiv skugga" och tycks vara bifigurer i en byråkratisk kamp.

Även andra undersökningar visar att tjänstemän inom den sociala vårdsektorn tenderar att sätta kollegorna i fokus. Sociologen Pithouse (1985) som studerat socialarbetare noterar att när de redovisar sitt arbete är det arbetskamrater och inte klienter man refererar till. På ett liknande sätt var det bristande intresset för klienterna talande i Meeuwisses (1996) analys av ett socialarbetarprojekt. Få ville ta del av den klientundersökning hon genomfört, och trots att ett av dem initialt eftersökt grannskapsarbete, flydde socialsekreterarna snart grannskapet: kontoret med kollegial gemensamhet var mer lockande.

Upptagenheten vid administrativa angelägenheter syns även i en policyetnografisk undersökning av ett samverkansprojekt kring invandrarintroduktion. Författarna noterar en "iögonfallande byråkratisk upptagenhet" parad med ett ointresse för målgruppen, invandrarna, i text och tal hos tjänstemännen (Carlsson och Jacobsson 2007). Även i ett tidigare vårdkedjeprojekt som Statens institutionsstyrelse drivit, förekom uppenbarligen detta relativa ointresse: "Det som, något oväntat, inte tas upp i särskilt stor utsträckning vid samtalen om syftet med projektet med VPK [vårdkedjeprojekt] är klienterna och vad dessa förväntas uppnå efter vården", skriver utvärderaren Jessica Palm (2007:172).

Samma slutsats kan vi dra. Flera olika yrkesrepresentanter finns representerade i projektet; en mängd "social-yrken" är involverade. De som interagerar mest intensivt är emellertid samordnarna och socialarbetarna, som med en viss antagen äganderätt söker bevaka "sina ärenden". Vare sig den ena eller den andra kategorin hade tilldelats en överordning. Socialarbetarna har formell makt men samordnarna är å andra sidan tillsatta för att bevaka samordningen av olika insatser - dvs. i viss mån att övervaka socialarbetarna. För bägge parter gäller uppenbarligen, som Pithouse (1985) noterar, att en stor del av arbetet sker i möteslokaler där ägandetvister utspelas och där de yrkes- 
verksamma uppvisar sin professionalitet i samspel och konkurrens med kollegor.

Samspelet mellan samordnare och socialtjänstens anställda uttrycks i våra intervjuer ofta i konflikttermer, något som avspeglar dessa relationers starka involvering, om man följer den sociologiske klassikern Georg Simmels (1970/1908) analyser av konflikter. För honom är nämligen konflikt ett uttryck för engagemang. Samtidigt visade det sig i den "effektutvärdering" som utförts av projektet att en stor andel av samordnarna ansåg sig ha särskilt goda relationer med socialtjänsten, bättre än med ungdomar och deras föräldrar (Andersson et al. 2010:71-74). Det är svårt att entydigt förklara denna diskrepans. Kanske kan det vara så att konflikterna och motståndet "sticker ut" från det samarbete som fungerar och rullar på, men att de involverade uppehåller sig vid konflikterna i våra intervjuer därför att de indikerar att den egna yrkesrollen är ifrågasatt.

Sammantaget kan projektet, som involverade en stor ekonomisk och personell satsning, åskådliggöra en viktig paradox. Det var tänkt att övervinna motsättningar, kolliderande reglementen och byråkratiska ordningar mellan alltmer specialiserade och byråkratiserade institutioner: Samordnarna skulle då fungera som en slags överbryggare, tolkare eller förmedlare av konkreta personers speciella behov, önskningar och behov av meriter.

Samordnarna kunde därmed sägas förkroppsliga en form av hopp om att överbrygga den järnbur, som var en av Max Webers (1968) farhågor då han analyserade den framväxande byråkratiseringen, styrd av formell rationalitet. I de involverades språkbruk kan denna farhåga kopplas till den ökade specialiseringen av organisationer, som var och en styrs av sitt eget byråkratiska regelverk; vårdkedjeprojektet legitimerades med uttalanden som: «Ungdomarna skall $\mathrm{nu}$ inte längre falla mellan (myndigheternas) stolarna".

Trots detta producerar de yrkesverksamma nya järnburar i form av en alltmer förtätad mötesverklighet.

I denna mening kan projektet med anställda ungdomssamordnare, som så småningom blir administrativa samordnare, tillsammans med de liknande fallstudier som refererats ovan, vara instruktivt och kanske illustrera en mer allmängiltig samtida tendens. Analysen kan kasta ett visst indirekt ljus över samverkansprojekts ineffektivitet, höga transaktionskostnader och tidsspillan då olika professionella kulturer, organisationer och yrkeskategorier skall integreras (Bergmark och Lundström 2005, Wiklund 2007): de professionella tycks orientera sig mot varandra istället för mot klienten, och deras förhandlingar och konflikter sker till stor del under skilda mötesformer.

Samverkan bjuder så att säga på en inbyggd konkurrens och en kontinuerlig jämförelse med andra yrkesrepresentanter och inbjuder därmed till ett försvar för den egna organisationen och yrkesidentiteten, något som hanteras genom möteskulturen. Strider om vem som skall agera ordförande, konflikter om de bästa behandlingsdokumenten och den tidsmässiga konkurrensen mellan möten, kan därför ske på bekostnad av det ursprungliga syftet: att förbättra ungdomarnas situation. Effektutvärderingens slutsats var: nollresultat (Andersson et al. 2010). 


\section{Referenser}

Agar, Michael (1994) Language Schock. Perennial: New York.

Andersson, Gunvor (1995) Barn i samhällsvård. Studentlitteratur: Lund.

Andersson, Maria, Lundström, Tommy och Sallnäs, Marie (2010) Utvärdering av förstärkt vårdkedja. Stockholms universitet.

Asplund, Johan (1987) Om hälsningsceremonier, mikromakt och asocial pratsamhet. Göteborg: Korpen.

Atkinson, M.A., Cuff, E.C. och Lee, J.R.E. (1978) The recommencement of a meeting. I Schenken, Jim (red.), Studies in the organization of conversational interaction. New York: Academic press.

Carlsson, Marie och Jacobsson, Bengt (2007) Tvärsektoriell samverkan i teori och praktik. I Gunnar Alsmark, m.fl. (red.) Inklusions- och exklusionsprocesser i Skandinavien. Makadam: Lund.

Basic, Goran, Thelander, Joakim och Åkerström, Malin (2009) Vårdkedja för ungdomar eller professionella? Stockholm: Statens institutionsstyrelse.

Bergmark, Åke och Lundström, Tommy (2005) Med förenade krafter? Socionomernas forskningssupplement, 17:2-11.

Brown, Roger (1986) Social-Psychology. Free Press: New York.

Degner, Jurgen och Henriksson, Anna (2007) Placerade utanför sitt sammanhang. Studies in Social Work: Örebro universitet.

Emerson, Robert, Fretz, Rachel och Shaw, Linda (1995) Writing Ethnographic Fieldnotes. Chicago: Chicago University Press.

Harnett, Tove (2010) Seeking exemptions from nursing home routines. Journal of Aging Studies, 24:4, 292-301.

Holstein, James och Gubrium, Jaber (1998) Active Interviewing. I David Silverman, (red.) Qualitative Research. Theory, Method and Practice. London: Sage. 113-129.

Holstein, James och Gubrium, Jaber (2003) A Constructionist Analytics for Social Problems. I James Holstein och Gale Miller (red.) Chal- lenges and Choices. New York: Aldine de Gruyter.

Goffman, Erving (1974) Jaget och maskerna. Stockholm: Rabén och Sjögren.

Goffman, Erving. 1967/1982. Where the Action Is. I Interaction Ritual. Pantheon: New York.

Huxham, Chris och Beech, Nic (2008) Interorganizational Power. I Steve Cropper (red.), The Oxford Handbook of Inter-Organizational Relations. Oxford: Oxford University Press. 555579.

Jacobsson, Katarina (2000) Retoriska strider. Lund. Palmkron.

Lipsky, Michael (1980) Street-Level Bureaucracy. Dilemmas of the Individual in Public Services. New York: Russell Sage.

Mansbridge, Jane (1983) Beyond Adversary Democracy. University of Chicago Press: Chicago.

Meeuwisse, Anna (1996) Projektets dolda funktioner. I Ingrid Sahlin, (red.) Projektets paradoxer. Lund: Studentlitteratur.

Palm, Jessica (2007) Implementeringen. I Varrdkedjeprojektet - Tre utvärderingsperspektiv. Stockholm: Statens institutionsstyrelse.

Perrow, Charles (1991) A Society of Organizations. Theory and Society, 15:725-62.

Pithouse, Andrew (1985) Poor Visibility: Case talk and collegial assessment in a social work office. Work and Occupations, 12:1:77-89.

Romano, Nicholas och Nunamaker, Jay (2001) Meeting Analysis: Findings from Research and Practice. Proceedings of the $34^{\text {th }}$ Hawaiii International Conference on System Sciences.

Sahlin, Ingrid (1996) Projektets paradoxer. Lund: Studentlitteratur.

Sallnäs, Marie; Vinnerljung, Bo; Westermark, Pia Kyhle (2004) Breakdown of teenage placements in Swedish foster and residential care. Child \& Family Social Work, 9, 2, 141-152.

Schwartzman, Helen (1989) The Meeting. New York: Plenum Press.

Simmel, Georg (1970/1908) Kamp! Lund: Argos.

SiS i Fokus, 2008, nr 1, omslag, reportage, 8-14.

Sluten ungdomsvård - En uppföljning. (2002) Stockholm: Brottsförebyggande rådet, Statens 
institutionsstyrelse och Socialstyrelsen.

Stein, Mike (2006) Young People Leaving Care.

Child and Family Social Work, 11:3:273-279.

Sulkanen, Pekka (2007) Re-inventing the social contract. Acta Sociologica, 50:3:325-333.

Weber, Max (1968) Economy and Society. New

York: Bedminster Press.

Wiklund, Stefan (2007) United we stand? Interna- tional Journal of Social Welfare, 16:3:202-211.

Åkerström, Malin, Jacobsson, Katarina och Wästerfors, David (2007) Reanalysis of Previously Collected Material. I Seale, Clive, Gubrium, Jaber och Silverman, David. Qualitative Research Practice. London: Sage.

\section{Summary}

\section{The meeting culture in a juvenile care chain}

This article concerns a large-scale evaluation of a project concerning Swedish juvenile care. The project was set up as a "carechain" involving various authorities, and a number of coordinators were employed to facilitate youngsters' "after-care" when they had left the special approved homes of the National Board of Institutional Care. Even though the original goals of the project stated that the coordinators were to plan the care in close cooperation with youngsters and their parents, a strong administrative orientation soon became apparent.

The coordinators were strongly committed to meetings and documents, they reviewed and assessed each other using a bureaucratic language rather than discussing the individual young person with commitment. In fact the young people rather fell into a discursive shadow when reading the interviews and field observations. This orientation became more visible as the three-year project ran its course; an indication of this was that originally the coordinators were called "youth coordinators" initially, but as time went on this changed to them being referred to only as "coordinators".

In this article one aspect of the administrative orientation is analysed: the "meeting culture". This is discussed as regards the forms of meetings, where categories of meetings are presented, with analysis of involvement, competition, and meeting conflicts and power struggles in meetings. It is suggested that this case illustrates an important paradox: coordinators or case workers may be employed to help concrete clients to overcome bureaucratic specialization, and to bridge specific organizational rules and regulations, by personalizing help and support. In this, as perhaps in other cases, they may reinvent the "iron cages" of modern bureaucracy. 